\title{
Environmental tritium around a new CANDU nuclear power plant
}

\author{
N. Paunescu, D. Galeriu and N. Mocanu \\ National Institute of R\&D for Physics and Nuclear Engineering-Horia Nulubei, \\ 407 Atomistilor Str., Com. Magurele, Jud. IIfov, P.O. Box MG-6, 76900 Bucharest, Romania
}

\begin{abstract}
In the routine operation of a nuclear power plant radioactive wastes are generated. Excepting ${ }^{3} \mathrm{H}$ and ${ }^{14} \mathrm{C}$, the quantities of radionuclides released during normal operation of CANDU 6, are smaller than emissions of other NPP. The tritium inventory and the tritium releases for classical and future (improved) CANDU 6 were theoretically evaluated and compared with the published data of CANDU 6 reactors with more than 10 years of operation. The tritium releases increases with time and no equilibrium is reached in the 30 years.

The environmental tritium level before and after the start of the Romanian CANDU 6 reactor was determined by analysis of different samples: air, water, soil, and vegetation. During the pre-operational period, the tritium concentration was low and almost uniform $(\sim 3 \mathrm{~Bq} / \mathrm{L})$, as for an area without local contamination sources other than common atmospheric fallout. In the first years of the reactor activity, the tritium concentration in environment was low, but more variable than pre-operation period. In the vicinity of the reactor, the tritium concentration in air, soil and spontaneous vegetation was till two orders of magnitude higher than the values measured during the preoperational level. The dose estimation for the maximum exposed individual, consuming local products, is $1.6 \mu \mathrm{Sv} / \mathrm{y}$.
\end{abstract}

\section{INTRODUCTION}

In December 1996, a CANDU 6 reactor was put into operation in Cernavoda town, in SE area of Romania, between the Danube River and the Danube-Black Sea Canal. The local agricultural land use is intensive, cereals, fruits and grapes being the major agricultural products.

In the routine operation of a nuclear power plant (NPP) the gaseous, liquid and solid wastes with various fission and activation radionuclides are generated. The design of the CANDU 6 reactor ensures that the releases are minimized, but small quantities of gaseous and liquid wastes are continuously discharged at very low concentrations. Excepting ${ }^{3} \mathrm{H}$ and ${ }^{14} \mathrm{C}$, the quantities of radionuclides released during normal operation, are smaller than emissions of other NPP.

\section{THE REFERENCE ROUTINE SOURCE TERM ASSESSMENT}

The tritium inventory and the tritium releases for classical and future (improved) CANDU 6 were theoretically evaluated and compared with the published data of CANDU 6 reactors with more than 10 years of operation (Point Lepreau and Gentily 2 in Canada, Embalse in Argentine and Wolsong 1 in Korea) [1]. For a given CANDU plant, tritium inventory is a function of power level, capacity factor and release rate. To calculate tritium inventory, the following were assumed:

- Coolant and moderator are completely separated;

- Complete mixing of total heavy water inventory within the systems;

- Make-up flow rates are equal to release flow rates, or the heavy water inventories in the systems are constant;

- Recovered coolant is returned to the coolant system, recovered moderator is returned to the moderator system;

- Plant average capacity factor is $84.4 \%$. 
The mass balance equation for tritium was [1]:

$$
\frac{\mathrm{d}(\mathrm{MN})}{\mathrm{dt}}=\phi \sigma \mathrm{N}_{\mathrm{D}} \mathrm{m} \mathrm{a}+\mathrm{F} \mathrm{No}-\lambda \mathrm{MN}-\mathrm{LN}
$$

Where the right side terms are, respectively, the tritium generation rate, the tritium content of heavy water, the natural decay rate and the tritium release rate. The definition of parameters are: $\mathrm{N}$ - the number of tritium atoms per $\mathrm{kg}$ heavy water; a - plant capacity factor; $\mathrm{L}$ - heavy water loss rate $(\mathrm{kg} / \mathrm{s}) ; \mathrm{N}_{0}$ - tritium in make-up flow $\left(\mathrm{kg}^{-1}\right)$, assumed zero; $N_{D}$ number of deuterium per $\mathrm{kg}$ heavy water; $\mathrm{M}$ and m mass of total and under neutron flux, heavy water $(\mathrm{kg}) ; \lambda$ - tritium decay constant; $\sigma$ - neutron absorption cross section; $\phi$ - thermal neutron flux; $F$ is make-up flow rate $(\mathrm{kg} / \mathrm{s})$ equal with the loss rate.

The tritium release increases with time and no equilibrium is reached in the first 30 years. The variation of tritium releases are represented in Figure 1, for experimental values and for theoretical assessment of present (pres) and future, improved CANDU reactor (next).

In Table 1 are presented the total releases of Cernavoda reactor [2] and the theoretical assessment of releases. The releases of Cernavoda reactor are expressed as ratio of Derived Emission Limits (DEL), where DEL is evaluated for $1 \mathrm{mSv} /$ year dose for population. In 2000 year the gaseous releases were about $0.4 \%$ of $\mathrm{DEL}$, and the increasing trend is visible.

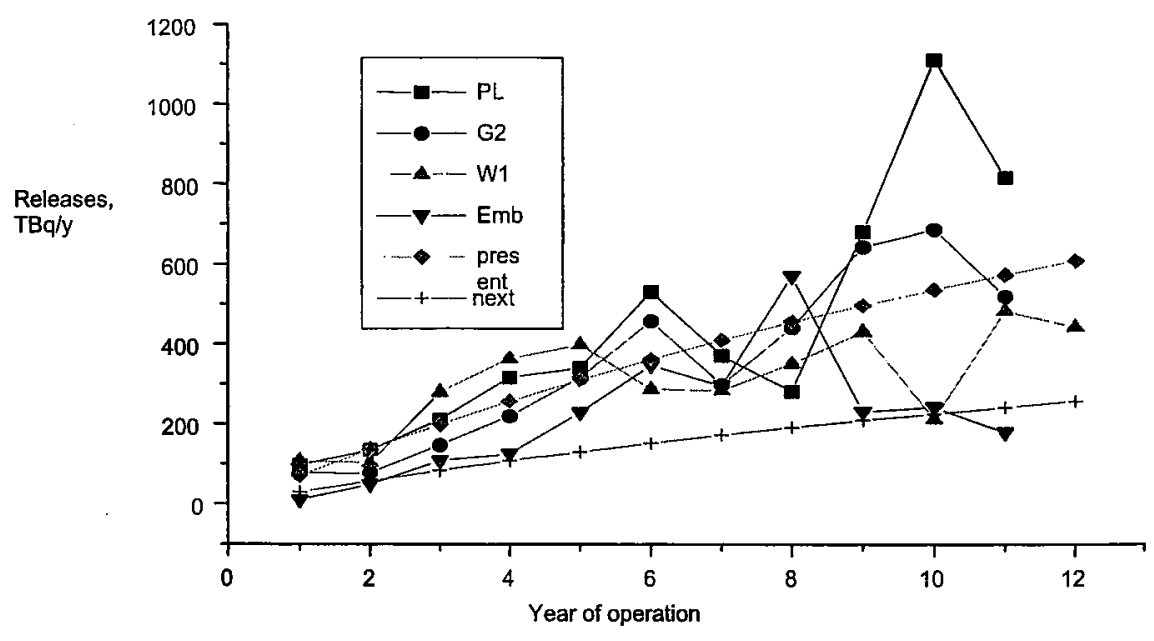

Figure 1: Yearly releases from CANDU 6 and predicted releases for standard CANDU 6, actual and new design. (PL =Point Lepreau, G2=Gentilly 2, W 1= Wolsong $1, \mathrm{Emb}=$ Embalse, pres= theoretical releases, next $=$ the assessment of tritium release of the improved CANDU)

Table 1: Liquid and gaseous releases of Cernavoda NPP during 31 December 1996-31 December 2000, and theoretical estimation of releases.

\begin{tabular}{|c|c|c|c|c|c|c|}
\hline \multirow[t]{2}{*}{ Year } & \multicolumn{2}{|c|}{$\begin{array}{c}\text { Gaseous releases } \\
\text { (Annual DELs: } 5.310^{13} \mathbf{~ k B q} \text { ) }\end{array}$} & \multicolumn{2}{|c|}{$\begin{array}{c}\text { Liquid releases } \\
\text { (Annual DELs: } 7.310^{13} \mathrm{kBq} \text { ) }\end{array}$} & \multirow{2}{*}{$\begin{array}{c}\text { Total emissions, } \\
\text { Exp. }\end{array}$} & \multirow{2}{*}{$\begin{array}{c}\begin{array}{c}\text { Total emissions, } \\
\text { theoretical }\end{array} \\
10^{12} \mathrm{~Bq} / \text { year }\end{array}$} \\
\hline & $\begin{array}{l}\text { Total \% } \\
\text { LDE }\end{array}$ & $10^{12} \mathrm{~Bq} /$ year & Total \% LDE & $10^{12} \mathrm{~Bq} /$ year & & \\
\hline $\begin{array}{c}1996 \\
(\sim 1 / 2 \text { year }) \\
\end{array}$ & $2.6110^{-3}$ & 1.4 & $1.6210^{-2}$ & 11.8 & 13.2 & $\sim 40$ \\
\hline 1997 & $4.8810^{-2}$ & 26 & $1.65810^{-2}$ & 12.12 & 38.12 & 70.4 \\
\hline 1998 & $9.6710^{-2}$ & 51 & $1.110^{-1}$ & 80.14 & 131,14 & 136 \\
\hline 1999 & $1.6210^{-1}$ & 85.9 & $3.2510^{-2}$ & 23.7 & 109.6 & 198 \\
\hline 2000 & $3.9710^{-1}$ & 210 & $8.09 .10^{-2}$ & 59.06 & 269.06 & 310 \\
\hline
\end{tabular}


The experimental determined tritium in gaseous and liquid releases of Cernavoda NPP is in the same range with other CANDU reactors in operation, and very close to the theoretical values deduced by using Wolsong 1 operating experience.

Tritium is emitted into atmosphere 3-4 times more than to aquatic pathway, predominantly as HTO $(>98 \%)$.

\section{EXPERIMENTAL}

The environmental tritium level was determined by analyses of different samples: air, water (Danube River, Danube-Black Sea Canal, drinking and ground, rain); soil water; tissue free water in vegetal and animal foodstuff. Organically bound tritium in cereal grains was determined by combustion in a Parr bomb, under $20 \mathrm{~atm}$ pressure of Oxygen.

The methods for sampling and treatment of different kinds of samples for extraction of water are presented in [3-5]. Briefly, tritium in air was determined by dynamic methods -on molecular sieves or in bubblers with water - and with passive samplers supplied by AECL. The soil cores of $0-5 \mathrm{~cm}$ and $5-10 \mathrm{~cm}$ length were taken. Soil samples and vegetation were azeotropic distilled with toluene for water extraction. Liquid scintillation analyser TRICARB 1900 TR and two types of scintillation cocktails (Instagel and Pico Fluor LLT) were used for measurement of tritium concentration in water. The detection limit (2 sigma error) was $3 \mathrm{~Bq} / \mathrm{L}$ for a counting time of 500 minutes.

The tritium concentration before the start (1994-1996) of the Cernavoda NPP in all environmental samples was low and almost uniform $(\sim 3 \mathrm{~Bq} / \mathrm{L})$, as for an area without local contamination sources. The occurrence of tritium in these samples was from common fallout.

After the start of NPP (December 1996), the measurement of the same environmental samples is going on, in the influence area of NPP and in a reference area.

\subsection{Tritium in air}

The concentration of tritium in air was measured at different distances (200 $\mathrm{m}$ to $2500 \mathrm{~m}$ ) and in different sectors, and in a reference area at $30 \mathrm{~km}$. In the sampling points from the vicinity of the reactor, the concentration of tritium in air is highest at $200 \mathrm{~m}$ from reactor, the nearest sampling point. At $800-2500 \mathrm{~m}$ from reactor, the influence of wind frequency and of the relief is evident. In sector S, where the wind frequency is high, the concentration of tritium in air is higher than in sector SV, where the wind frequency is also high, but between reactor and sampling point is a water pool. In Figure 2 is presented the variation of tritium in air concentration with the distance from the reactor. At distances larger than $3 \mathrm{~km}$ the influence of tritium emissions is very small, after four years of operation of the reactor.

\subsection{Tritium in soil and plants}

Deposition of tritium on the soil is the result of the interaction of a number of processes. Atmospheric releases reach the soil by rainout of tritiated water (wet deposition), diffusion of tritiated water vapour (dry deposition), deposition and oxidation of tritiated hydrogen gas. After deposition, most of the tritium is in the water form and moves with the bulk of the soil water by miscible displacement as it infiltrates deeper into the soil. Reemission of tritiated water from soil is also possible. Water is absorbed by the roots of vegetation and re-enters the atmosphere by transpiration of the plants [6]. The plants absorb the atmospheric water vapours by leaves. As a result, the tritium concentration in soil moisture and in tissue free water of the plants follows the tritium in air concentration, decreasing with the distance from the reactor. In Fig. 2 are presented the variation with distance from reactor of tritium concentration in air, in soil and in tissue water of plant (TWT) in 1999. In spontaneous vegetation and soil, tritium concentration is similar in magnitude. 


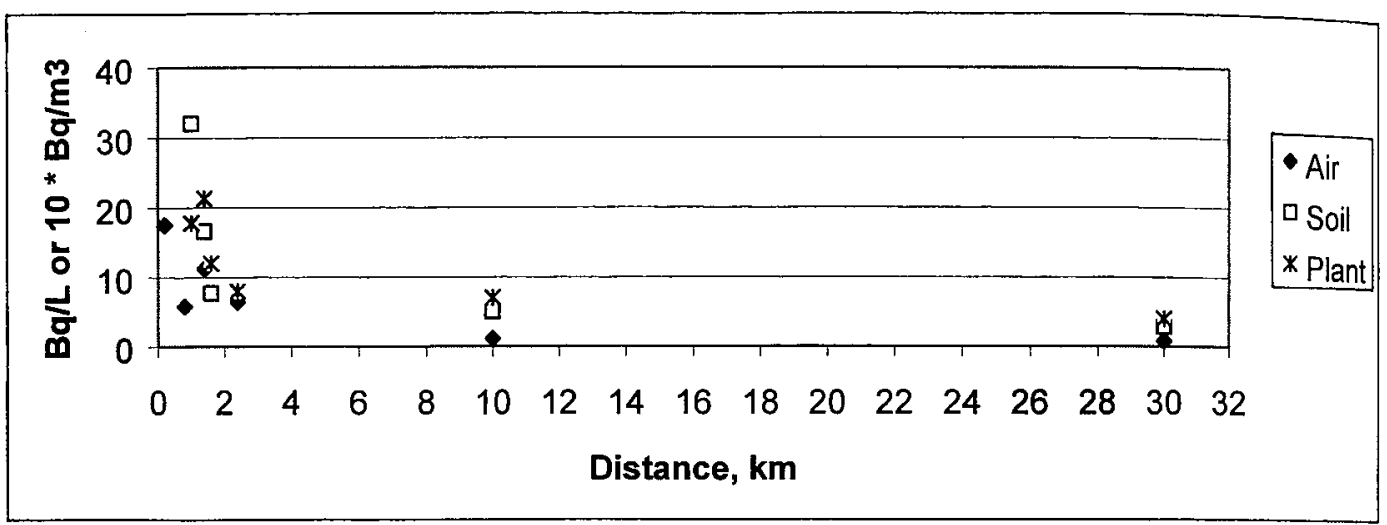

Figure 2: The variation of tritium concentration in air, soil and plant water with distance from reactor, in 1999

It was observed a different concentration of tritium in water of cultivated and ploughed soils, comparing to uncultivated, natural vegetated soil. Tritium concentration in water from cultivated soil is always smaller than in uncultivated soil (Table 2), at the same distance from reactor. The cultivated soil is more permeable, and the reemission of tritium is possible to be higher than in undisturbed soil. In the same time, the migration of water in the deeper layers of ploughed soil is higher.

Table 2: Concentration of tritium in soil water (in parentheses is the number of the samples)

\begin{tabular}{|c|cc|cc|}
\hline Year & Cultivated soil (Bq/L) & \multicolumn{2}{|c|}{$\begin{array}{c}\text { Natural vegetated soil } \\
(\mathbf{B q} / \mathbf{L})\end{array}$} \\
\hline 1997 & $4.2 \pm 0.6$ & $(1)$ & & $(4)$ \\
\hline 1998 & $11.3 \pm 7.5$ & $(4)$ & $16.6 \pm 5.5$ & $(5)$ \\
\hline 1999 & $12.7 \pm 4.9$ & $(3)$ & $21.3 \pm 13.4$ & $(8)$ \\
\hline 2000 & $17.5 \pm 5.5$ & $(4)$ & $91 \pm 47$ & \\
\hline
\end{tabular}

The average concentration for all the samples in the area with a radius of $2500 \mathrm{~m}$ from the reactor shows evidently the increasing trend of tritium concentration in the influence area of CANDU reactor (Figure 3), although the concentration of tritium after four years of operation of CANDU reactor is still very small. To make a comparison, the maximum allowed concentration by Romanian standard is 4000 $\mathrm{Bq} / \mathrm{L}$ of drinking water.

\subsubsection{Tritium in cultivated plants}

Beginning with 1996, the most representative types of vegetation for Cernavoda area and as contributor to human diet were sampled and analysed: vegetable (potatoes, tomatoes, onions, bean, peas etc.), cereals (wheat, corn, barley) and fruits (peach, apricot, grapes). Generally, the tritium in tissue water was very low, below $10 \mathrm{~Bq} / \mathrm{L}$. In the last year, the grapes from the vineyard in the vicinity of reactor $(\sim 1600 \mathrm{~m})$ have an increased content of tritium $(21.6 \pm 2.9 \mathrm{~Bq} / \mathrm{L})$. In the area of $3 \mathrm{~km}$ radius are not others inportant cultivated plots.

The organically bound tritium was measured in cereals (wheat, corn and barley) grown at longer distances from the reactor $(8-30 \mathrm{~km})$. Comparing with the pre-operational values, no differences were found, concentration of organically bound tritium being between 2.5 and $4 \mathrm{~Bq} / \mathrm{L}$ of combusted water. These concentrations correspond to values $<2 \mathrm{~Bq} / \mathrm{kg}$ fresh weight of organically bound tritium.

The maximum concentration for total tritium (in tissue water and organically bound) in cereals was $(2.8 \pm 1.3) \mathrm{Bq} / \mathrm{kg}$ fresh weight. Most of the values were below the detection limit of the methods. 


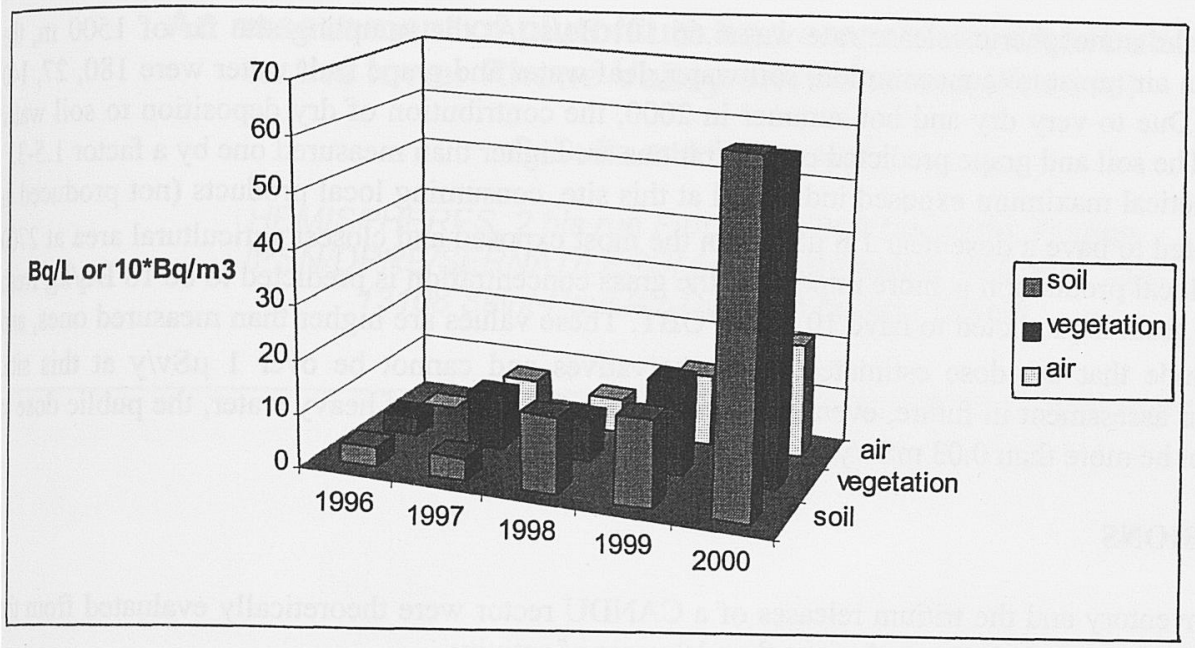

Figure 3: Annual averages concentration in Cernavoda area $(2500 \mathrm{~m})$ in soil water $(\mathrm{Bq} / \mathrm{L})$, tissue water of spontaneous iegetation $(\mathrm{Bq} / \mathrm{L})$ and air $\left(10 * \mathrm{~Bq} / \mathrm{m}^{3}\right)$

\subsection{Tritium in water}

The sources of drinking water in the towns and villages are ground water or/and water of the Danube River. In both situations, the concentration of tritium in drinking water is not influenced by the reactor :leases; the tritium concentration is frequently below the detection limit $(\sim 3 \mathrm{~Bq} / \mathrm{L})$.

The liquid releases are eliminated in the Danube River or, sometimes, in the Danube-Black Sea Canal. The influence of these releases is small, only seldom the tritium concentration being higher than nomal concentration for the surface water. The maximum concentration in the Danube River or the Danube-Black Sea Canal was one order of magnitude higher than normal values.

\section{DOSE ASSESSMENT}

A model for dose assessment during the normal operation of the reactor was elaborated [7] considering the main processes during the exposure of the population to the routine emissions of a heavy water reactor. The model correct the deficiency of the Canadian guide [8] considering the contribution of organically bound tritium ingested or created in organism after the ingestion of HTO. The contribution of cereals, oils and sugar from diet and the dry deposition of tritium to soil are considered. Transfer factors for animal products were derived by using a metabolic approach [9] and allowance was permitted for drinking water contamination and local consumption.

An evaluation of the supplementary doses for people working or leaving in the vicinity of reactor was made with this model, by using the specific parameters for Cernavoda area. The total dose for ingestion, inhalation and skin absorption was evaluated. The model cannot be applied in the exclusion zone, but only inhalation of workers was assessed to be less than $0.5 \mu \mathrm{Sv} / \mathrm{y}$ at a larger distance than $200 \mathrm{~m}$ from the reactor 
In 2000 , the atmospheric release rate was $6.6610^{6} \mathrm{~Bq} / \mathrm{s}$. At the sampling site far of $1500 \mathrm{~m}$, the predicted mean air moisture concentration, soil water, leaf water and grape fruit water were 180, 27, 140 and $66 \mathrm{~Bq} / \mathrm{L}$. Due to very dry and hot summer in 2000 , the contribution of dry deposition to soil water was ignored. The soil and grape predicted concentrations are higher than measured one by a factor 1.5-3.

A hypothetical maximum exposed individual at this site, consuming local products (not produced in fact) is estimated to have a dose near $1.6 \mu \mathrm{Sv} / \mathrm{y}$. In the most exposed and closest agricultural area at 2700 $\mathrm{m}$, where the local production is more important, the grass concentration is predicted to be $18 \mathrm{~Bq} / \mathrm{kg}$ fresh weight, while grain is predicted to have $10 \mathrm{~Bq} / \mathrm{kg}$ OBT. These values are higher than measured ones, and we can conclude that the dose estimates are conservatives and cannot be over $1 \mu \mathrm{Sv} / \mathrm{y}$ at this site. Prolonging our assessment in future, even in the case of no detritiation of heavy water, the public dose at this site cannot be more than $0.03 \mathrm{mSv} / \mathrm{y}$.

\section{CONCLUSIONS}

The tritium inventory and the tritium releases of a CANDU rector were theoretically evaluated from the experience of heavy water reactor with more than 10 years of activity.

In the first four years of activity, the experimental determined tritium in gaseous and liquid releases of Romanian CANDU reactor, from Cernavoda town, was in the same range with other CANDU reactors releases, and very close to the theoretical values.

In the first years of the reactor activity, the tritium concentration in environmental samples was low, but more variable as before the start of the reactor. The influence of tritium releases is small, but evident. In the samples from the vicinity of the reactor, in an area with about $2500 \mathrm{~m}$ radius, the tritium concentration in air, in soil and spontaneous vegetation was 1-2 order of magnitude higher than the value during the pre-operational level.

Wind frequency and relief influence the concentration of tritium in air: is higher in the sector with high wind frequency; is smaller in the sector with a water pool.

In ploughed, cultivated plot, in soil water the tritium concentration is smaller than in uncultivated, natural vegetated plot. The concentration in tissue water and in organically bound tritium of cultivated plants is still low, very close of pre-operational level.

Routine emission gives trivial dose to public around.

\section{Acknowledgments}

Work partially supported by our Center of Excellence IDRANAP under Contract with European Commission ICA-CT-2000-70023/12.02.2001

\section{References}

[1] D. Galeriu, A. Melintescu, Gh. Mateescu, Rom. J. Phys., 44, 997, (1999)

[2] Rapport de Informare, IR 96200-02, IR 96200-03, IR 96200-04, IR 96200-05

[3] N. Paunescu, M. Cotarlea, D. Gáleriu, et al., J. Radioanal. Nucl. Chem. 239(3), 465 (1999)

[4] M. Cotarlea, N. Paunescu, D. Galeriu, et al. Rom. J. Phys., 43 (1-2) 147, (1998)

[5] N. Paunescu, M. Cotarlea, L. Purghel et al., Romanian J. Physics, 40(2-3), 363, (1995)

[6] Y. Belot, M. Roy and H. Metivier, in "Le tritium de l'environnement à l'homme", ed. by H. Metivier

(Les Editions de Physique, 1996)

[7] D. Galeriu, personal communication; to be published

[8] National Standard of Canada, CAN/CSA-N288.1-M87

[9] D. Galeriu, A. Melintescu, N. Beresford, N. Crout, this conference 